\title{
An Assessment of economic and environmental benefits of desilting village tanks in Sri Lanka: An application of linear programming
}

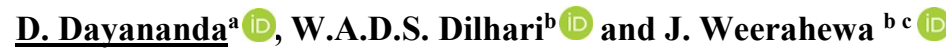 \\ ${ }^{a}$ Postgraduate Institute of Agriculture, University of Peradeniya, Sri Lanka, ${ }^{b}$ Department of Agricultural \\ Economics and Business Management, Faculty of Agriculture, University of Peradeniya, 'School of Food \\ and Agriculture, University of Melbourne, Australia. \\ Email:dasuni447@gmail.com
} \begin{abstract}
in terms of ecosystem benefits. The objective of this paper is to assess the returns on investments of desiltation of village tanks in Sri Lanka's Dry Zone. The study employs a cost-benefit analysis to compare the cost of alternative desiltation scenarios with the economic and environmental benefits of desiltation of three village tanks in Mahakanumulla village in Anuradhapura District. A Linear Programming (LP) model was developed and simulated to assess the profitability of crop cultivation under tank desiltation with and without market interventions. The benefits of regulating, supporting and cultural services were assessed under various hypothetical scenarios. The simulation results of the LP model indicate that desiltation does not bring in significant benefits if market interventions are not present. The rates of returns to investments are higher with a $25 \%$ desiltation compared to that of $50 \%$, implying that the degree of desiltation also matters. Furthermore, the findings reveal that when values of multiple eco-system services are accounted, desiltation strategies bring in positive returns. Partial desiltation along with market interventions are recommended to cover the cost of investments on minor tank rehabilitation.
\end{abstract}

Abstract: Village tanks are climate smart irrigation infrastructures predominant in the Dry Zone of Sri Lanka from ancient times. They have degraded over time, and the rehabilitation of tanks has become a dire need of the society. Out of the many rehabilitation approaches, the removal of silt, commonly known as desiltation, has been the most widely used approach. Desiltation increases the availability of irrigation water by increasing storage capacity of the tanks. In addition to increasing irrigation potential, desilting has many positive impacts

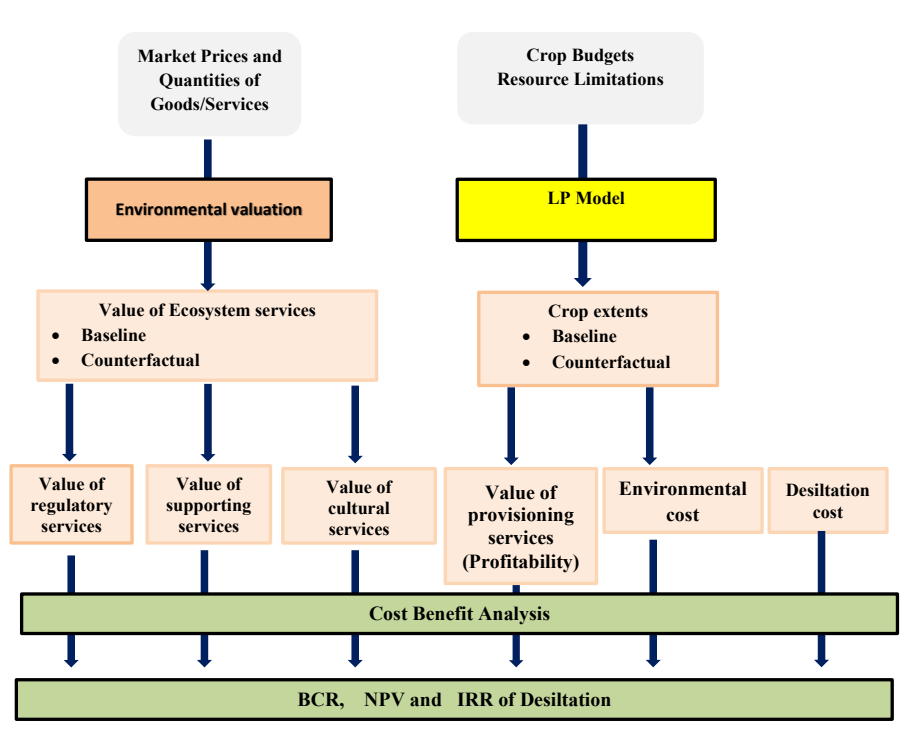

Figure 1. Approach for assessing economic and environmental benefits of desilting village tanks

Keywords: Desiltation, linear programming model, cost-benefit analysis, ecosystem benefits 
Dayananda et al., An Assessment of Economic and Environmental Benefits of Desilting Village Tanks in Sri Lanka: An Application of Linear Programming

\section{INTRODUCTION}

Irrigation has been identified as the key to agricultural transformation in developing countries particularly in arid and semi-arid climate zones. Irrigation infrastructures are of two types: major and minor irrigation systems. The latter was predominantly constructed and managed by agrarian communities whereas the establishment and operation of the former has been mainly done by the national governments. The minor irrigation systems in many countries have degraded over time due to various political interventions and changes in socioeconomic conditions.

Considering the benefits of rehabilitating such systems, various international and national agencies and civil society organizations adopted several strategies to renovate them. These include the removal of excess sediment or silt, structural repairs (sluices, spills, canals, waterways, drainages, field culverts etc.), tank ecosystem development, tank catchment development, and the promotion of other development activities such as infrastructure, livestock, fishery, agro-based industry, cottage industry and institutional development etc. (IUCN, 2015). Among these, the removal of silt, commonly known as desiltation, has been the most widely used strategy (Tiwari et al. 2011).

Desiltation increases the availability of irrigation water by increasing tanks' storage potential through manipulating the geometry and reducing tank water loss (Dharmasena, 2004). Moreover, it has the potential to enhance the values of the entire ecosystem (IUCN 2015; Dharmasena, 1994). According to Dharmasena (1994 and 2000) with partial desiltation, as opposed to complete desiltation, about half the extent that has been filled with water would become a free land which is fertile with soil organic matter content that ranges between 5 $8 \%$. Additionally, it is moist under the influence of ground water, and the new area that emerges from the tank bed after desiltation can also be utilized for other purposes such as grazing grounds for livestock, thereby increasing the availability of fodder for the animals. Dharmasena (2000) also suggests that, with partial desilting, an adequate dead storage will be available which will be favorable for rearing even long-lifespan fish species and, can likewise be utilized for raising fingerlings in protected areas. Furthermore, increased water storage will also contribute towards maintaining the groundwater table and increase the availability of water for drinking and domestic use (IUCN, 2015). According to Tiwari et al. (2011), as a result of tank desiltation, there has been significant improvement in groundwater levels in the villages of drought-prone Chitradurga District in Karnataka, India, and is reported to have reduced flood risks in the area. Babu and Manasi (2008) stated that desilting operations were not only economically viable but they also had additional benefits such as environmental protection, increased soil microbial biodiversity, improved soil quality and increased water storage in India's mid Godavari basin. Desilting affects aquatic flora positively where it enhances the sustenance of submerged, emergent and floating plants. It also supports a varied and stable habitat with diverse niches for fauna thereby indirectly extending the food web by supporting natural predators. Moreover, through restoration interventions in tanks, villagers may engage more in cultural events owing to increasing activity in tank-based agriculture which will in turn enhance the social dignity of communities, and provide meaning to their cultural traditions (IUCN, 2015). Bekoe et al. (2021) accounted for multiple ecosystem services such as livestock watering, fisheries, recreation services, domestic water, and climate regulation in computing returns on investment in the rehabilitation of multipurpose small reservoirs in Northern Ghana.

According to the authors' knowledge, no attempt has been made to date to assess the economic and environmental benefits of desiltation. The objective of this paper is to assess the returns on investments on desiltation interventions for a selected three village tanks in the Dry Zone of Sri Lanka. This employs a costbenefit analysis to compare the cost of alternative desiltation scenarios with the economic and environmental benefits of desiltation. The economic benefits to the on-site communities are assessed using a Linear Programming (LP) model while environmental benefits are assessed using simulation.

\section{METHODOLOGY}

\subsection{Study Site}

Mahakanumulla tank village in the Anuradhapura District was selected as the study area. It has three interconnected tanks namely Mahakanumulla, Mawathawewa and Galwaduwawewa which spread across $647,000 \mathrm{~m}^{2}, 138,000 \mathrm{~m}^{2}$ and $45,000 \mathrm{~m}^{2}$, respectively. A map of the area is shown in Figure 2. The irrigation infrastructure of the village is being maintained by the Department of Agrarian Services in Thirappane. One hundred

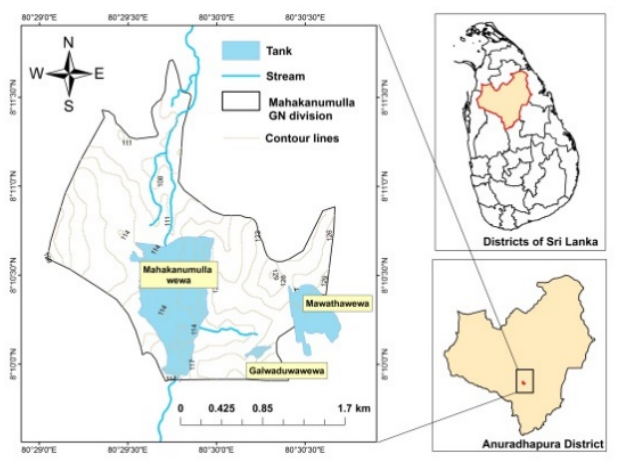

Figure 2. Mahakanumulla GN division 
Dayananda et al., An Assessment of Economic and Environmental Benefits of Desilting Village Tanks in Sri Lanka: An Application of Linear Programming

and twelve (112) households live in the village, and their primary occupation is farming.

Tank water is used for multiple purposes including bathing, washing, animal wallowing, and, industries to some extent. The village consists of 97.22 ha of lowland and 18.21 ha of upland. Both annual Yala (dry season) and Maha (wet season) seasons are used for cultivation of a variety of crops including paddy, maize and low country vegetables. Rainfall, groundwater, and tank-stored water are the three main water sources for agriculture.

Tanks in Mahakanumulla provide a variety of other ecosystem services in addition to the above provisioning services. These include different provisioning services (domestic water supply, animal grazing, water for animals, fisheries and flowers from the tank), regulating services (water quality and flood control), supporting services (cascade biodiversity), and cultural services (recreational and bird watching). Dilhari and Weerahewa (2021) evaluated the aggregate value of such ecosystem services. The provisional services were valued using a combination of economic valuation approaches namely direct market valuation approaches such as market prices, surrogate prices and opportunity cost approaches. The three other types of services were valued using benefit transfer approaches such as unit adjusted value transfer and meta-analytic function transfer methods. The value of provisioning, regulatory, supporting and cultural services of Mahakanumulla was reported as 169,800 USD/ha, 246,300 USD/ha, $82800 \mathrm{USD} / \mathrm{ha}$ and $140 \mathrm{USD} / \mathrm{ha}$, respectively. Accordingly, the aggregate value of the ecosystem services under consideration was $424,520 \mathrm{USD} /$ ha. The value of the net profit per household per annum in Mahakanumulla GN Division is approximately 4,400 USD.

\subsection{Cost Benefit Analysis}

\section{Assessment of Desiltation Costs:}

According to the current market prices in Sri Lanka, the desiltation cost per square meter is 1.21 USD (Provincial Irrigation Department, 2019). The total desiltation cost was calculated paying heed to the water spread area of the three tanks. The cost of desiltation at $25 \%$ desiltation and $50 \%$ desiltation were calculated separately for the three tanks and summed to obtain the total costs of desiltation.

\section{Assessment of Irrigation Benefits: Linear Programming Model}

A linear programming model was developed and simulated to analyze the profitability under tank desiltation and market interventions. The general form of the linear programming model is given below:

$$
\begin{aligned}
& \text { Objective function: } \\
& \operatorname{Max} Z=\sum_{j=1}^{n} C_{j} x_{j} \\
& \begin{array}{l}
\text { Subject to, } \\
\sum_{i=1}^{m} \mathrm{a}_{\mathrm{ij}} \mathrm{x}_{\mathrm{j}}\{\leq,=, \geq\} \mathrm{b}_{\mathrm{i}} \forall i
\end{array} \\
& Z=\text { Profit } \\
& C_{j}=\text { co-efficient of the } j^{\text {th }} \text { decision variable } \\
& a_{i j}=j^{\text {th }} \text { coefficient of the } i^{\text {th }} \text { constraint; } \\
& X_{j}=j^{\text {th }} \text { decision variable } \\
& b_{i}=i^{\text {th }} \text { resource limit. }
\end{aligned}
$$

$x_{i} \geq 0$

Two labour constraints (hired and family), 12 water constraints (representing the 12 months) and 4 land constraints (lowland and upland for both seasons) were considered. The activities and constraints were specified to cover the two main seasons of crop cultivation.

Firstly, the main constraints of the village tank system were identified using data gathered from a key informant survey and secondary sources. The key informants were the Agriculture Research Inspector for Mahakanumulla, the President of the Mahakanumulla Farmers' Organization, and the individuals responsible for water operations for a particular season. Water, land and labour are the major constraints of the Mahakanumulla village tank system. The baseline model calibrated using the 18 different constraints. Crop Water Requirements (CWRs) was calculated using the CROPWAT model of the Food and Agriculture Organization (FAO) using the Mahailuppallama Weather Station data (Table 1). 
Dayananda et al., An Assessment of Economic and Environmental Benefits of Desilting Village Tanks in Sri Lanka: An Application of Linear Programming

Table 1. Profitability, labour usage and CWR of crops in Maha and Yala seasons in the Anuradhapura District

\begin{tabular}{|c|c|c|c|c|c|c|c|}
\hline Criteria & Units & Paddy & Maize & Vegetable & $\begin{array}{c}\text { Maize } \\
\text { buyback }\end{array}$ & $\begin{array}{r}\text { Tobacco } \\
\text { buyback }\end{array}$ & Data source \\
\hline Profit & USD/ha & 465 & 1,082 & 729 & 2,757 & 1,847 & $\begin{array}{c}\text { Cost of Cultivation publications } \\
\text { (DOA), IPS (2021), Champika et } \\
\text { al.(2014) }\end{array}$ \\
\hline \multirow{2}{*}{ CWR } & $\mathrm{m} /$ Maha season & 0.606 & 0.359 & 0.322 & 0.359 & 0.333 & \multirow{2}{*}{$\begin{array}{l}\text { Authors' calculation using FAO } \\
\text { CROPWAT }\end{array}$} \\
\hline & $\mathrm{m} /$ Yala season & 0.731 & 0.480 & 0.409 & 0.480 & 0.423 & \\
\hline Labor & $\begin{array}{c}\text { Man } \\
\text { days/ha/season }\end{array}$ & 47 & 76 & 140 & 76 & 200 & $\begin{array}{l}\text { Cost of Cultivation publications } \\
\text { (DOA) }\end{array}$ \\
\hline
\end{tabular}

The limits on water constraints were modified to reflect $25 \%$ and $50 \%$ tank desiltation scenarios and simulated five times considering the potential siltation after the desiltation effort. According to a key-informant of Department of Irrigation, annual siltation would approximately be 5\% if further investments are not made. The government and private sector-driven market interventions were simulated under each desiltation scenarios by changing the crop combinations in the LP model. The introduction of a maize and tobacco buy-back systems in the crop plans were the market interventions.

Environmental degradation owing to crop cultivation was evaluated using previous estimates on soil loss and Nitrate leaching (Table 2). The amount of Nitrate leaching was calculated bearing in mind the rates of fertilizer application recommended by the Department of Agriculture (Table 2). The Nitrate leaching amount was calculated using estimates of Dayananda et al., (2021).

Table 2. Summary of the Environmental Sustainability Calculation

\begin{tabular}{|c|c|c|c|c|c|c|c|}
\hline & Crop & Units & Paddy & Maize & Vegetable & Tobacco & Data Source \\
\hline \multirow{2}{*}{$\begin{array}{l}\text { Soil loss } \\
\text { estimation }\end{array}$} & Soil loss & Tons/ha & 5 & 10 & 10 & 75 & Krishnarajah, 1982 \\
\hline & Cost of Soil loss & USD/ha & 0.49 & 0.97 & 0.97 & 7.29 & Authors' calculation \\
\hline \multirow{7}{*}{$\begin{array}{c}\text { Nitrate } \\
\text { leaching } \\
\text { estimation }\end{array}$} & Fertilizer usage $^{1}$ & $\mathrm{~kg} / \mathrm{ha}$ & 200 & 280 & 35 & 600 & Department of Agriculture \\
\hline & N\% in Fertilizer & $\%$ & 46 & 46 & 46 & 12 & Department of Agriculture \\
\hline & Estimated $\mathrm{N}$ rate & $\mathrm{kg} / \mathrm{ha}$ & 92 & 129 & 16 & 72 & Authors' calculation \\
\hline & Nitrate Leaching in Maha & $\mathrm{kg} / \mathrm{ha}$ & 33 & 40 & 23 & 49 & \multirow{2}{*}{ Dayananda et al, 2021} \\
\hline & Nitrate Leaching in Yala & $\mathrm{kg} / \mathrm{ha}$ & 21 & 26 & 13 & 33 & \\
\hline & $\begin{array}{c}\text { Cost of Nitrate leaching in } \\
\text { Maha season }\end{array}$ & USD/ha & 3.67 & 4.41 & 2.51 & 3.32 & Authors' calculation \\
\hline & $\begin{array}{c}\text { Cost of Nitrate leaching in } \\
\text { Yala season }\end{array}$ & USD/ha & 2.30 & 2.87 & 1.46 & 2.04 & Authors' calculation \\
\hline
\end{tabular}

${ }^{1}$ Urea for paddy, maize and vegetables and YaraMila for tobacco

\section{Assessment of Other Benefits to the Ecosystem}

The benefits from the desiltation of other ecosystem services were calculated under two scenarios; Scenario 1: assuming that ecosystem benefits increase by $5 \%$ and $10 \%$ at $25 \%$ and $50 \%$ desiltation, respectively and Scenario 2: assuming that ecosystem benefits increase by $10 \%$ and $20 \%$ at $25 \%$ and $50 \%$ desiltation, respectively, over a period of five years. Values of the ecosystem services computed by Dilhari and Weerahewa (2021) were treated as baseline values.

\section{Measures of project worth}

The Net Present Value (NPV), Benefit Cost Ratio (BCR) and Internal Rate of Return (IRR) were calculated to measure project worth assuming the project benefit period as five years. A $10 \%$ discount rate was employed to calculate financial return of the project. Incremental benefits from the baseline were used to measure project benefits. NPV is the difference between the sums of the present value of discounted benefit streams and cost streams over the lifetime of the project; it is the present worth of the net cash flow streams at a chosen 
Dayananda et al., An Assessment of Economic and Environmental Benefits of Desilting Village Tanks in Sri Lanka: An Application of Linear Programming

discounted rate. The decision rule using NPV as a decision criterion is to accept the project with positive NPV and reject if its NPV is negative. BCR is an indicator denoting the relationship between the relative costs and benefits of a proposed project, expressed in monetary or qualitative terms. If a project has a BCR greater than 1.0 , the project is expected to deliver a positive net present value to a firm and its investors.

IRR is the discount rate that needs to be applied to generate the NPV of the project to zero over the series of discounted net cash flows of a project. IRR represents the average earning power of the funds invested in the project over the life of the project. The decision rule when using IRR is to accept and invest in projects having IRR equal or above the opportunity cost of capital.

$$
\begin{array}{lll}
\mathrm{NPV}=\sum_{\mathrm{i}=1}^{t} \frac{\left(B^{t}-C^{t}\right)}{(1+\mathrm{d})^{\mathrm{t}}} & \text { (3) } & \mathrm{B}^{\mathrm{t}}=\text { total value of benefit streams at time ' } t \\
\mathrm{BCR}=\frac{\sum_{t=1}^{t} \frac{(B t)}{(1+d)^{t}}}{\sum_{t=1}^{t} \frac{\left(C_{t}\right)}{(1+d)^{t}}} & \text { (4) } & \mathrm{C}^{\mathrm{t}}=\text { total value of cost streams at time ' } t \\
\mathrm{IRR} \sum_{\mathrm{i}=1}^{t} \frac{\left(B^{t}-C^{t}\right)}{(1+\mathrm{d})^{\mathrm{t}}}=0 & \text { (5) } & \mathrm{d}=\text { discount rate and }
\end{array}
$$

\section{RESULTS AND DISCUSSION}

\section{Optimal farm plans under alternative desiltation scenarios:}

The results of the simulation of the LP model demonstrate increases in profitability of crop cultivation owing to increases in water availability under different market interventions (see Table 3 for the optimal crop plans

\begin{tabular}{|c|c|c|c|c|c|c|c|c|c|c|}
\hline \multirow[t]{2}{*}{ Scenario } & \multicolumn{6}{|c|}{ Cultivation extent - Maha Season (ha) } & \multicolumn{4}{|c|}{ Cultivation extent - Yala Season (ha) } \\
\hline & Rice & Maize & Vegetable & $\begin{array}{c}\text { Maize } \\
\text { buyback }\end{array}$ & Tobacco & Rice & Maize & Vegetable & $\begin{array}{c}\text { Maize } \\
\text { buyback }\end{array}$ & Tobacco \\
\hline Baseline & 97.21 & 2.50 & 0.88 & & & 39.54 & 0.83 & 1.45 & & \\
\hline $25 \%$ desiltation & 97.21 & 18.21 & 0 & & & 38.01 & 13.04 & 1.31 & & \\
\hline $50 \%$ desiltation & 97.21 & 18.21 & 0 & & & 47.40 & 13.04 & 1.84 & & \\
\hline $25 \%$ desiltation +Tobacco & 97.21 & 0 & 0 & & 18.21 & 36.19 & 0 & 0 & & 18.21 \\
\hline $50 \%$ desiltation +Tobacco & 97.21 & 0 & 0 & & 18.21 & 46.32 & 0 & 0 & & 18.21 \\
\hline $25 \%$ desiltation + Maize & 97.21 & 0 & 0 & 18.21 & & 38.01 & 0 & 1.31 & 13.04 & \\
\hline $50 \%$ desiltation + Maize & 97.21 & 0 & 0 & 18.21 & & 47.40 & 0 & 1.84 & 13.04 & \\
\hline
\end{tabular}
under alternative scenarios). At the baseline initial months of the Yala season (February) water constraints were binding (Table 4). Furthermore, for December in the Maha season and June in Yala season, water constraints

\begin{tabular}{|c|c|c|c|c|c|c|c|c|c|c|c|c|}
\hline Scenario & December & January & February & March & May & June & July & August & $\begin{array}{l}\text { Lowland } \\
\text { - Maha }\end{array}$ & $\begin{array}{l}\text { Upland } \\
\text { - Maha }\end{array}$ & $\begin{array}{l}\text { Lowland } \\
\text { - Yala }\end{array}$ & $\begin{array}{l}\text { Upland } \\
\text { - Yala }\end{array}$ \\
\hline Baseline & 3,585 & - & 196,475 & 665 & - & 2,647 & - & 17,540 & 51 & - & - & - \\
\hline $25 \%$ desiltation & - & 18,113 & - & - & - & 12,353 & 2,907 & 79,490 & 465 & 3,517 & - & - \\
\hline $50 \%$ desiltation & - & - & - & - & - & 12,353 & 2,907 & 79,490 & 2,325 & 4,326 & 1,082 & - \\
\hline $25 \%$ desiltation + Tobacco & 12,069 & - & - & - & - & 15,502 & - & - & 930 & 7,955 & - & 7,086 \\
\hline $50 \%$ desiltation + Tobacco & - & - & - & - & 3,036 & 12,401 & - & - & 2,325 & 9,237 & - & 7,133 \\
\hline $25 \%$ desiltation + Maize & - & 18,113 & - & - & - & 12,353 & 2,907 & 292,684 & 465 & 7,326 & - & 2,285 \\
\hline $50 \%$ desiltation + Maize & - & - & - & - & - & 12,353 & 2,907 & 292,684 & 2,325 & 13,787 & - & - \\
\hline
\end{tabular}
were binding while crops require high water demands for their mid-stage growth. When tank desiltation was coupled with market interventions, maize and/or tobacco cultivation were expanded allowing farmers to earn higher profits.

Table 3. Optimal crop mix under desiltation scenarios

Table 4. Shadow prices of constraints under each scenario (USD) 
Dayananda et al., An Assessment of Economic and Environmental Benefits of Desilting Village Tanks in Sri Lanka: An Application of Linear Programming

Source: Authors' calculations

The results show that profitability is higher when crop choices are expanded and that the environmental costs associated with market interventions depend on the types of crops introduced (Figure 3). As illustrated in Figure 3 , the introduction of tobacco to the system resulted in higher soil losses and Nitrogen leaching.

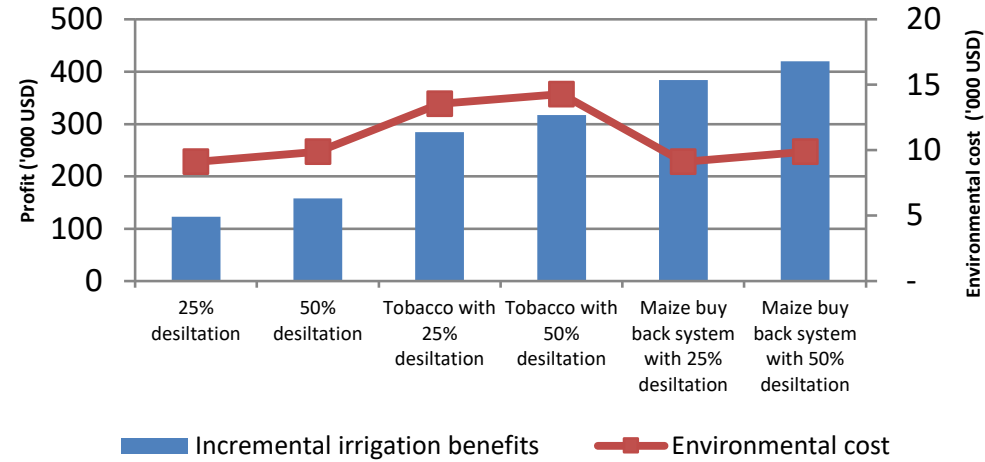

Figure 3. Incremental irrigation benefits and environmental cost Source: Authors' calculation
A $50 \%$ desiltation resulted in high irrigation benefits compared to that of the $25 \%$ desiltation under all scenarios. When the degree of desiltation increases, water availability in the Yala season increases. This is the source of increase in profitability. This finding supports Dharmasena (2004) also indicated that after desiltation tanks store redundant water in the Maha season for the Yala cultivation. Meanwhile the $50 \%$ desiltation rate led to

high environmental costs due to the expansion of cultivation extent. However, such investment leads to efficient use of land, water and labour resources and enhances private profitability.

Table 5 illustrates the increase in ecosystem benefits under assumed scenarios of desiltation.

Table 5. Assessing ecosystem benefits with desiltation

\begin{tabular}{llcc}
\hline & Scenario & $\begin{array}{c}\text { Provisioning services } \\
\text { (USD) }\end{array}$ & $\begin{array}{c}\text { Regulatory, Supporting and } \\
\text { Cultural services (USD) }\end{array}$ \\
\hline \multirow{2}{*}{$\mathbf{2 5 \%}$ desiltation } & Ecosystem benefits increase by 5\% & 24,523 & 36,789 \\
\cline { 2 - 4 } & Ecosystem benefits increase by 10\% & 50,939 & 76,418 \\
\hline \multirow{2}{*}{$\mathbf{5 0 \%}$ desiltation } & Ecosystem benefits increase by 10\% & 49,045 & 73,758 \\
\cline { 2 - 4 } & Ecosystem benefits increase by 20\% & 135,837 & 203,782 \\
\hline
\end{tabular}

Source: Authors' calculation

\section{Cost of desiltation Measures of project worth:}

The total costs for the $25 \%$ and 50\% desiltation were 251,743 USD and 503,487 USD respectively, according to the 2019 market prices (Table 2).

Table 6. Measures of project worth

\begin{tabular}{|c|c|c|c|c|c|c|c|c|c|}
\hline \multirow{2}{*}{ Scenario } & \multicolumn{3}{|c|}{ Without eco-system services } & \multicolumn{3}{|c|}{$\begin{array}{c}\text { With eco-system services- } \\
\text { Simulation } 1\end{array}$} & \multicolumn{3}{|c|}{$\begin{array}{l}\text { With eco-system services- } \\
\text { Simulation } 2\end{array}$} \\
\hline & $\begin{array}{l}\text { NPV } \\
\text { (USD) }\end{array}$ & BCR & IRR & $\begin{array}{c}\text { NPV } \\
\text { (USD) }\end{array}$ & BCR & IRR & $\begin{array}{l}\text { NPV } \\
\text { (USD) }\end{array}$ & BCR & IRR \\
\hline $25 \%$ desiltation & $-157,127$ & 0.38 & $-21 \%$ & $-108,544$ & 0.55 & $-12 \%$ & $-61,400$ & 0.76 & $-2 \%$ \\
\hline $\begin{array}{l}\text { 25\% desiltation } \\
\text { +Tobacco }\end{array}$ & $-34,573$ & 0.86 & $4 \%$ & 6,216 & 1.03 & $11 \%$ & 57,790 & 1.23 & $20 \%$ \\
\hline $\begin{array}{l}50 \% \text { desiltation } \\
+ \text { Tobacco }\end{array}$ & $-262,488$ & 0.48 & $-14 \%$ & $-164,326$ & 0.66 & $-5 \%$ & $-9,742$ & 0.98 & $9 \%$ \\
\hline $25 \%$ desiltation + Maize & 41,353 & 1.16 & $16 \%$ & 82,559 & 1.34 & $23 \%$ & 137,080 & 1.54 & $31 \%$ \\
\hline
\end{tabular}


Dayananda et al., An Assessment of Economic and Environmental Benefits of Desilting Village Tanks in Sri Lanka: An Application of Linear Programming

NPV, BCR and IRR were computed under two desiltation scenarios through alternative market interventions with and without incorporating eco-system services. According to the NPV, BCR and IRR results presented in Table 6 , it is evident that a $25 \%$ desiltation generates more returns compared to those with a $50 \%$ desiltation. It is clear that the direct costs of desilting village tanks in the study area are high compared with the benefits of irrigation. In the absence of market interventions, desiltation does not bring in additional benefits (Table 1 and Figure 2).

If eco-system services are included in the analysis, the scenarios with expanded crop choices yield higher returns of desiltation. A BCR of 1.54 resulted with $25 \%$ tank desiltation with the introduction of maize buyback marketing arrangement to the system. Under a 25\% partial desiltation, the market intervention of tobacco and maize buy-back system led to a positive return to the system.

\section{CONCLUSIONS AND POLICY IMPLICATIONS}

The results demonstrate clearly that traditional crop choices cannot generate a sufficient revenue to cover the cost of desiltation and that it has to be coupled with a market intervention such as maize buyback to make the investment worthwhile. The results of the LP model show that water constraints of initial and mid-growth stages, and the end stage of the Yala season after desiltation with market interventions are binding. Relaxing these binding constraints with appropriate interventions will be required to enhance profitability of farming.

\section{AKNOWLEDGEMENT}

This work was financially supported by the project grant of AHEAD/RA3/DOR/STEM/PDN/No 52 of University of Peradeniya, Sri Lanka.

\section{REFERENCES}

Babu, K.L. and Manasi, S., 2008. Estimation of ecosystem services of rejuvenated irrigation tanks: a case study in mid Godavari Basin. In International Water Management Institute Conference Papers (No. h042911).

Bekoe, J., Balana, B.B. and Nimoh, F., 2021. Social cost-benefit analysis of investment in rehabilitation of multipurpose small reservoirs in Northern Ghana using an ecosystem services-based approach. Ecosystem Services, 50, 101329.

Dayananda, D., Weerahewa, J. and Weerasooriya, S.A., 2021. An Evaluation of the Profitability and Environmental Sustainability of Cascade Systems under Various Technological and Market Interventions: A Case Study in Mahakanumulla. Conference on Cascade Ecology \& Management - 2021.Faculty of Agriculture, University of Peradeniya, Peradeniya, Sri Lanka, 17th \& 18th September 2021 pp 166-171.

Dayananda, D., Weerahewa, J. and Weerasooriya, S.A., 2021. Water Availability, Crop Choices and Profitability of Farming: A Case Study of Mahakanumulla Tank Village. Tropical Agricultural Research, 32(1), 81-94

Dilhari, W.A.D.S. and Weerahewa, J., 2021.Valuing Ecosystem Services Provided by Minor Village Tanks in the Dry Zone of Sri Lanka. Conference on Cascade Ecology \& Management - 2021.Faculty of Agriculture, University of Peradeniya, Peradeniya, Sri Lanka, 17th \& 18th September 2021 pp 139-143

Dharmasena, P.B., 1994, Tank-village system as a resource base for multi-purpose trees. In Proceedings of the 5th Regional Workshop on Multi-Purpose Trees, University of Peradeniya, Sri Lanka,1-3.

Dharmasena, P.B. and Gunasena, H.P.M., 2000. Towards efficient utilization of surface and ground water resources in food production under small tank system. Food Security and Small Tank Systems in Sri Lanka, 103-111.

Dharmasena, P. B., 2004. Exploring Tank-Village Farming System in the Dry Zone, Journal of Soil Sci. Soc. Sri Lanka, 16, 17-28.

IUCN, 2015. Project Implementation Plan. IUCN programme on Restoring Traditional Cascading Tank Systems Technical Note \# 1. Colombo: IUCN, International Union for Conservation of Nature, Colombo, Sri Lanka \& Government of Sri Lanka, 34.

Krishnarajah, P. (1982). Soil erosion and conservation in the upper Mahaweli watershed. Joachim Memorial Lecture-Annual Session of JSS.

Rosegrant, M.W., Ringler, C. and Zhu, T., 2009. Water for agriculture: maintaining food security under growing scarcity. Annual review of Environment and resources, 34, 205-222.

Tiwari, R., Somashekhar, H.I., Parama, V.R., Murthy, I.K., Kumar, M.M., Kumar, B.M., Parate, H., Varma, M., Malaviya, S., Rao, A.S. and Sengupta, A., 2011. MGNREGA for environmental service enhancement and vulnerability reduction: rapid appraisal in Chitradurga district, Karnataka. Economic and political weekly, 39-47. 